Jurnal Ilmu Sosial dan Pendidikan (JISIP)

Vol. 6, No. 1 Januari 2022

e-ISSN : 2656-6753, p-ISSN: 2598-9944

DOI: 10.36312/jisip.v6i1.2729/http://ejournal.mandalanursa.org/index.php/JISIP/index

\title{
Prosedur dan Efektifitas Mekanisme Penyelesaian Sengketa Perdagangan dan Investasi Dalam ASEAN
}

\author{
Fariz Mauldiansyah \\ Program Magister Hukum Universitas Indonesia
}

\section{Article Info}

Article history:

Received 17 Desember 2021

Publish 04 Januari 2022

\section{Keywords:}

Dispute Settlement, Trade,

EDSM, Investment, ACIA

\section{Info Artikel}

Article history:

Diterima 17 Desember 2021

Publis 04 Januari 2022

\begin{abstract}
Trade and investment play an important role in the practice of relations between countries in the prospective economic cooperation efforts to increase the economic growth of each country. In this regard, ASEAN also has legal instruments that regulate transactions and investments among other countries. In the trade regime, ASEAN has several agreements such as the ASEAN Free Trade Agreement, ASEAN Trade in Goods Agreement, ASEAN Trade in Services Agreement, ASEAN Framework Agreement on Services, and so on. Meanwhile in the investment regime, ASEAN has the ASEAN Comprehensive Investment Agreement. One of the important components in a Regional Trade Agreement is the clause of a legally binding dispute settlement mechanism. In the trade regime, the system and mechanism of the dispute resolution procedures are separated from other trade agreements, the ASEAN Protocol on the Enhanced Dispute Resolution Mechanism. Meanwhile in the Investment regime, the system and mechanism of the dispute resolution procedure are regulated in the same agreement in the ASEAN Comprehensive Investment Agreement. This article will describe the procedural mechanism for the dispute resolution framework of the trade and investment regime in ASEAN, as well as focus on each dispute resolution system with the preferences of each participating country, with differences in the use of the dispute system in the WTO.

Abstrak

Perdagangan dan investasi memegang peranan penting dalam praktik hubungan antar negara dalam upaya kerjasama di bidang ekonomi yang prospektif untuk meningkatkan pertumbuhan ekonomi masing-masing negara. Dalam hal tersebut, ASEAN juga memiliki instrumen hukum yang mengatur transaksi perdagangan dan investasi antar negara anggotanya. Pada rezim perdagangan, ASEAN memiliki beberapa perjanjian seperti ASEAN Free Trade Agreement, ASEAN Trade in Goods Agreement, ASEAN Trade in Services Agreement, ASEAN Framework Agreement on Services, dan lain sebagainya. Sedangkan pada rezim investasi, ASEAN memiliki ASEAN Comprehensive Investment Agreement. Salah satu komponen penting dalam sebuah Regional Trade Agreement adalah pengaturan mengenai penyelesaian sengketa yang legally binding. Dalam rezim perdagangan, sistem dan mekanisme penyelesaian sengketa diatur khusus dalam perjanjian terpisah, yakni ASEAN Procotol on Enhanced Dispute Settlement Mechanism. Sedangkan pada rezim Investasi, sistem dan mekanisme penyelesaian sengketa diatur dalam perjanjian yang sama pada ASEAN Comprehensive Investment Agreement. Artikel ini akan fokus untuk menguraikan mekanisme yang bersifat prosedural atas kerangka penyelesaian sengketa dari rezim perdagangan dan investasi di ASEAN, serta efektifitas dari masing-masing sistem penyelesaian sengketa yang dikaitkan dengan preferensi negara anggota ASEAN terhadap penggunaan sistem penyelesaian sengketa di WTO.
\end{abstract}

This is an open access article under the Lisensi Creative Commons Atribusi-BerbagiSerupa 4.0 Internasional

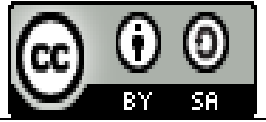




\section{Corresponding Author:}

Fariz Mauldiansyah

Program Magister Hukum Perdagangan Internasional, Universitas Indonesia

Email: farizmhnf@gmail.com

\section{PENDAhuluan}

Latar belakang terbentuknya Association of Southeast Asian Nations (ASEAN) adalah untuk menciptakan kerukunan dan rasa kekeluargaan yang tentu dilatarbelakangi oleh adanya pemikiran bahwa setiap negara di Asia Tenggara sejatinya adalah keluarga dan harus saling berhubungan dan bekerjasama baik secara ekonomi, politik, maupun budaya. Hal tersebut secara tidak langsung termuat dalam Pasal 1 (1) Piagam ASEAN, disebutkan bahwa ASEAN lahir untuk mempertahankan dan meningkatkan perdamaian, keamanan, dan stabilitas, serta memperkuat nilai-nilai yang berlandaskan perdamaian di dalam kawasan Asia Tenggara.

Perkembangan integrasi kawasan di ASEAN dimulai sejak 2003 pada KTT ASEAN IX di Bali. Pada konferensi tersebut terbentuklah Deklarasi ASEAN Concord II (Bali Concord II) yang menekankan pada pembentukan ASEAN Community sebagai komunitas yang aman, damai, stabil, dan sejahtera. Melalui tiga pilar ASEAN yang telah disebutkan dalam Bali Concord II dan kemudian ditegaskan kembali dalam Preamble Piagam ASEAN, membagi ASEAN Community ke dalam tiga pilar, yakni ASEAN Political-Security Community (APSC), ASEAN Economic Community (AEC), dan ASEAN Socio-Cultural Community (ASCC). APSC dalam hal ini bukanlah sebuah langkah koordinasi kebijakan luar negeri atau pakta pertahanan dan keamanan, namun justru mengedepankan adanya sovereign right yang dimiliki setiap negara untuk melakukan dan menjalankan kebijakan luar negeri dan politik keamanannya secara independen. Demikian juga dengan ASCC yang merupakan wujud kerjasama yang lebih intens dibidang sosial budaya. Pada Bali Concord II, yang menjadi perhatian utama adalah pada AEC dengan adanya deklarasi integrasi ekonomi ASEAN yang ingin dicapai pada tahun 2020, kemudian pada agenda terpisah di akselerasikan upaya pembentukan AEC pada tahun 2015. Integrasi ekonomi yang dimaksud dalam hal ini adalah kesepakatan anggota ASEAN untuk menciptakan "single market and production base" yang didasarkan pada "free flow of goods, services, investments, capital, and skilled labour". Hal tersebut diharapkan dapat memperkecil dan bahkan menghilangkan kesenjangan pertumbuhan ekonomi yang ada di kawasan Asia Tenggara.

Dengan berkembang pesatnya pertumbuhan organisasi regional di dunia, tentu memiliki potensi yang lebih besar terkait adanya ketidaksepakatan antar negara. Dalam mengantisipasi konflik yang timbul dari adanya ketidaksepakatan antar negara-negara, khususnya negara-negara anggota organisasi regional, sebuah mekanisme penyelesaian sengketa yang legally binding dinilai sebagai komponen yang penting dalam menunjang dan mempertahankan keberhasilan integrasi ekonomi regional. ASEAN sebagai organisasi regional dengan tiga pilar ASEAN Community merupakan sebuah kerangka pemikiran dan terobosan yang progresif, namun hal tersebut harus dikawal dengan suatu prosedur dan mekanisme penyelesaian sengketa yang mengikat secara hukum.

Sejarah perkembangan pengaturan penyelesaian sengketa di ASEAN dimulai pada saat terbentuknya Deklarasi Bangkok 1967 atau juga sering disebut Deklarasi ASEAN. Deklarasi ASEAN merupakan sebuah instrumen yang menjadi dasar kesepakatan negara-negara penandatangan (pada saat itu Filipina, Indonesia, Malaysia, Singapura, dan Thailand) untuk membentuk ASEAN sebagai organisasi regional. Namun ASEAN baru diberikan status sebagai badan yang memiliki legal personality melalui Charter of the Association of Southeast Asian Nations atau biasa disebut Piagam ASEAN.

Deklarasi ASEAN sebenarnya tidak secara spesifik mengatur mengenai penyelesaian sengketa, namun terdapat sebuah landasan filosofis yang menginginkan adanya komitmen negara anggota untuk menciptakan suasana damai, yang dimana dapat ditarik suatu makna bahwa dalam hal 
terjadinya persoalan atau ketidaksepakatan dalam kerjasama antar negara anggota, negara-negara diharapkan tetap memelihara perdamaian di kawasan Asia Tenggara. Hal tersebut berarti bahwa dalam hal terjadinya sengketa antar negara anggota, negara anggota diharuskan untuk menyelesaian sengketa secara damai.

Namun Deklarasi ASEAN bukan satu-satunya landasan negara anggota ASEAN dalam menyelesaikan sengketa. Treaty of Amity and Cooperation in the South-East Asia (TAC) yang ditandatangani pada tahun 1976, merupakan perjanjian pertama yang memiliki pengaturan terkait penyelesaian sengketa. Salah satu poin penting dalam TAC adalah kewajiban negara untuk menghargai kedaulatan negara lain dan menetapkan prosedur penyelesaian sengketa secara damai. Pada dasarnya setiap perjanjian ASEAN mewajibkan komitmen para pihak dalam menjalankan muatan perjanjiannya serta dalam hal terjadinya sengketa, harus dilakukan dengan cara yang damai melalui mekanisme-mekanisme seperti negosiasi, mediasi, konsiliasi, arbitrase, dan judicial settlement.

Kemudian pada tahun 1996 terdapat sebuah instrumen yang mengatur mengenai penyelesaian sengketa, yakni the Protocol on Dispute Settlement Mechanism. Namun perjanjian tersebut kemudian digantikan dengan ASEAN Protocol on Enhanced Dispute Settlement Mechanism (EDSM) pada tahun 2004. EDSM merupakan sebuah manifestasi dari keinginan negara anggota ASEAN untuk memiliki instrumen yang memuat penyelesaian sengketa di bidang kerjasama ekonomi.

Perkembangan pengaturan penyelesaian sengketa di ASEAN tidak berhenti di EDSM. Pada tahun 2007, negara-negara anggota ASEAN mengesahkan Piagam ASEAN yang kemudian memperkuat kedudukan Deklarasi ASEAN sebagai instrumen pendirian ASEAN dengan diberikannya status kepada ASEAN sebagai organisasi regional yang memiliki legal personality. Hal tersebut termuat dalam Pasal 3 Piagam ASEAN yang menyatakan: "ASEAN, as an intergovernmental organization, is hereby conferred legal personality”. Sebenarnya ketentuan penyelesaian sengketa dalam Piagam ASEAN hanya memuat pengaturan-pengaturan yang sebelumnya sudah pernah diatur dalam TAC dan EDSM, serta acuannya terhadap Pasal 33 (1) Piagam PBB.

Namun meskipun terdapat berbagai perjanjian yang mengikat negara-negara ASEAN, tidak dapat dipungkiri bahwa ASEAN tidak memiliki lembaga atau institusi yang mengatur dan mengawasi kepatuhan negara-negara anggota dalam menjalankan kewajiban dalam perjanjiannya. Baru sejak terbentuknya Piagam ASEAN, ASEAN memiliki instrumen yang mengatur mengenai mekanisme penyelesaian sengketa yang sifatnya legally binding. Dapat dikatakan bahwa sebelum terbentuknya Piagam ASEAN, eksistensi ASEAN dan keberlanjutan ASEAN hanya bergantung pada itikad baik negara-negara anggota saja.

Selain itu, dengan disebutkannya bahwa ASEAN menginginkan adanya integrasi ekonomi di negara-negara kawasan Asia Tenggara dengan cara "free flow of goods, services, investments, capital, and skilled labour", maka dengan demikian cita-cita tersebut tidak hanya terbatas pada integrasi di bidang perdagangan barang dan jasa saja, namun juga di bidang investasi. Instrumen penting ASEAN terkait investasi adalah ASEAN Comprehensive Investment Agreement (ACIA). Secara singkat ASEAN juga mengatur mengenai penyelesaian sengketa investasi antara negaranegara anggota ASEAN dengan investor asing. Dengan demikian kerjasama ekonomi di ASEAN terbagi menjadi dua, yakni kerjasama ekonomi di bidang perdagangan, dan kerjasama ekonomi di bidang investasi.

Berkaitan dengan penyelesaian sengketa di ASEAN, fokus artikel ini adalah mengenai penyelesaian sengketa pada rezim perdagangan dan pada rezim investasi investasi dalam ASEAN. Artikel ini akan dibagi dalam dua pembahasan, yakni pembahasan pertama mengenai Penyelesaian Sengketa Perdagangan di ASEAN melalui EDSM, dan pembahasan kedua mengenai Penyelesaian Sengketa Investasi di ASEAN melalui ACIA. 


\section{METODE PENELITIAN}

Penulisan artikel ini merupakan tipe penulisan yuridis normatif yaitu penulisan yang berdasar pada penemuan aturan hukum, prinsip-prinsip hukum, maupun doktrin hukum yang sesuai untuk melakukan perbandingan atas mekanisme penyelesaian sengketa perdagangan dan investasi di ASEAN, serta untuk menilai efektifitas dari penggunaan EDSM dan DSM ACIA. Metode pendekatan yang digunakan dalam penulisan artikel ini adalah dengan menggunakan Statute Approach, Conceptual Approach, dan Comparative Approach.

\section{HASIL PENELITIAN DAN PEMBAHASAN}

\subsection{Penyelesaian Sengketa Perdagangan Melalui ASEAN Protocol on Enhanced Dispute Settlement Mechanism}

Ruang lingkup daripada EDSM ini adalah berfokus pada sengketa yang berkaitan dengan ekonomi. Sengketa ekonomi ini adalah sengketa yang timbul dari pelaksanaan (hak dan kewajiban) dan sengketa terkait penafsiran dari perjanjian perjanjian ekonomi yang negaranegara ASEAN telah sepakati. Di dalam Appendix I, EDSM memuat perjanjian-perjanjian yang tercakup dan tunduk pada EDSM ini. Terdapat 46 perjanjian ekonomi di dalamnya, termasuk perjanjian yang penting, antara lain ASEAN Framework Agreement on Service (1995), ASEAN Agreement on Customs (1997) dan lain sebagainya.

Dalam hal terjadinya sengketa dan dalam hal mengupayakan penyelesaian sengketa melalui prosedur dan mekanisme yang diatur dalam EDSM, pihak bersengketa dapat mengajukan permintaan ke Senior Economic Officials Meeting (SEOM) untuk membentuk panel sesuai dengan Pasal 5 (1) EDSM. Namun dalam Pasal 1 yang membahas mengenai Coverage and Application, pada ayat (3) menyebutkan bahwa dalam hal terjadinya sengketa antar negara anggota ASEAN, pihak bersengketa diberikan kebebasan untuk mencari alternatif penyelesaian melalui forum atau lembaga penyelesaian sengketa lainnya. Maka dengan kata lain hendak menjelaskan bahwa ketentuan-ketentuan EDSM sifatnya lebih fleksibel karena tidak mengurangi hak negara-negara anggota untuk mengupayakannya jalan lain untuk penyelesaian sengketa yang melibatkan negara anggota lainnya.

Kemudian apabila pihak bersengketa menyetujui untuk menyelesaikan sengketanya melalui SEOM, maka SEOM akan bertindak sesuai EDSM dan kemudian membentuk dan mengadopsi panel report, serta Appellate Body Report. SEOM dan badan-badan ASEAN terkait lainnya akan diberitahu tentang solusi yang disepakati bersama dan hal-hal yang secara resmi diangkat berdasarkan ketentuan mengenai konsultasi dan penyelesaian sengketa yang tercakup dalam perjanjian.

Pada tahapan pertama, pihak bersengketa sebelumnya harus terlebih dahulu melakukan konsultasi. Dalam mengupayakan konsultasi, pihak bersengketa yang dirugikan harus mengajukan permohonan konsultasi dan memberitahukan permohonan konsultasi tersebut secara tertulis kepada SEOM dengan memberikan penjelasan mengenai alasan dibuatnya permohonan konsultasi seperti permasalahan yang disengketakan dan dasar hukum klaim tersebut. Jika permohonan konsultasi telah dibuat, negara anggota yang bersangkutan harus menjawab permintaan konsultasi tersebut dalam kurun waktu 10 hari setelah tanggal penerimaan permohonan konsultasi dan harus mengadakan konsultasi dalam jangka waktu 30 hari setelah tanggal penerimaan permohonan konsultasi. Dalam kasus yang mendesak termasuk yang menyangkut perishable goods - para pihak yang bersengketa, panel dan Appelate Body (AB) harus melakukan segala upaya untuk mempercepat proses secepat mungkin. Namun jika tidak ditemukan hasil dari konsultasi tersebut dan tidak menemukan titik terang maka kemudian semua hasil konsultasi tersebut harus diberitahukan kepada SEOM untuk dilakukannya upaya penyelesaian sengketa dengan motode yang lain, yakni melalui jasa-jasa 
baik, konsiliasi, dan mediasi sebagaimana diatur dalam Pasal 4 (1) EDSM. Pada proses ini, sebenarnya pihak bersengketa diberikan keleluasaan untuk mengupayakan mekanisme yang lebih diplomatis. Namun apabila setelah melalui mekanisme tersebut para pihak bersengketa tetap tidak dapat menemukan titik terang, maka SEOM selanjutnya dapat membentuk panel.

Pembentukan panel ini sebenarnya tidak perlu menunggu hasil konsultasi terlebih dahulu. Dalam hal ketika permohonan konsultasi yang diajukan pihak bersengketa yang dirugikan tidak dijawab selama 10 hari oleh pihak yang bersangkutan (sejak diajukannya permohonan konsultasi), atau dalam setelah diajukannya permohonan konsultasi pihak yang bersengketa tidak mengadakan konsultasi (dalam kurun waktu 30 hari setelah diajukannya permohonan konsultasi), atau dalam hal ketika konsultasi berhasil dilaksanakan namun tidak menemukan kesepakatan dalam kurun waktu 60 hari setelah diajukannya permohonan konsultasi, maka SEOM dapat membentuk panel. Panel dibentuk dengan berdasarkan Terms of Reference of Panels yang tercantum dalam Pasal 6 EDSM.

Panel yang dibentuk oleh SEOM ini sebenarnya sama seperti panel yang ada dalam Dispute Settlement Mechanism WTO (DSM WTO), dimana panel membuat penafsiran objektif terkait permasalahan yang disengketakan, termasuk melihat kembali fakta-fakta yang terdapat dalam kasus dan keterkaitannya dengan perjanjian EDSM atau perjanjian relevan lainnya yang tercakup dalam EDSM, dan bertugas memberikan findings, rulings, dan recommendations yang tepat dalam rangka penyelesaian sengketa antara pihak yang bersengketa.

Setelah panel membuat penafsiran, temuan, dan rekomendasi yang berkaitan dengan kasus, panel harus menyampaikan hasilnya kepada SEOM dalam bentuk laporan tertulis dan dalam kurun waktu 60 hari sejak dibentuknya panel. Namun dalam keadaan tertentu, panel diberikan perpanjangan waktu selama 10 hari untuk menyampaikan panel report nya. Sebelum panel memberikan panel report nya kepada SEOM, negara pihak bersengketa harus diberikan kesempatan untuk mereview hasil report tersebut.

Setelah diberikannya panel report kepada SEOM, SEOM harus mengadopsi panel report tersebut dalam kurun waktu 30 hari setelah diberikannya panel report kepada SEOM. Namun apabila terdapat pihak bersengketa yang mengajukan banding, maka pengadopsian yang dilakukan oleh SEOM harus menunggu sampai proses banding melalui AB telah dilaksanakan sebagaimana tertuang dalam Pasal 9 (1) EDSM. Namun dalam hal tidak adanya pertemuan SEOM, pengadopsian panel report tersebut "shall be done by circulation", artinya, pengadopsian panel report dapat dilaksanakan dengan diedarkannya panel report tersebut kepada seluruh anggota ASEAN. Apabila setelah diberikannya panel report dan pihak bersengketa tidak memberikan sanggahannya untung membanding hasil panel report tersebut, maka SEOM dapat mengasumsikan bahwa pihak yang bersengketa telah setuju mengenai hasil panel report tersebut.

Menjadi hal yang wajar ketika pihak bersengketa tidak sepakat dengan hasil panel report. Hal tersebut juga demikian dalam DSM WTO. Dalam rangka pihak bersengketa (salah satu atau keduanya) mengajukan permohonan banding, maka langkah selanjutnya adalah proses banding yang akan dilakukan oleh $\mathrm{AB}$. AB dibentuk (atau diangkat) oleh ASEAN Economic Ministers (AEM) yang mana anggota $\mathrm{AB}$ akan menjalani tugasnya selama satu periode (4 tahun), dan masa jabatannya hanya dapat diperpanjang satu kali. AB terdiri dari tujuh orang dan setidaknya tiga dari setiap anggota tersebut harus ada dalam setiap kasus. Hal ini sama seperti AB yang ada di WTO, dimana dalam menangani proses banding, AB tidak boleh terdiri kurang dari 3 orang.

Sebagai aturan umum, proses pelaksanaan banding melalui AB tidak akan melebihi 60 hari sejak salah satu pihak bersengketa secara resmi memberitahukan keputusannya untuk mengajukan banding ke AB. Hal yang cukup menarik adalah pengaturan dalam Pasal 12 (9) yang menjelaskan bahwa pelaksanaan AB harus dirahasiakan. Dalam hal ini EDSM mengupayakan confidentiality atas informasi yang diberikan oleh para pihak. Lalu AB report 
dapat dirancang tanpa kehadiran para pihak yang bersengketa dan berdasarkan informasi disediakan dan pernyataan yang telah dibuat.

Ruang lingkup $\mathrm{AB}$ terbatas pada permasahan hukum yang ada dalam panel report, dan mengenai kesalahan interpretasi hukum yang dilakukan oleh panel. Dalam hal ini AB dapat mendukung, mengubah, atau bahkan membalikkan temuan hukum dan kesimpulan dari panel report. Kemudian setelah dikeluarkannya $\mathrm{AB}$ report, $\mathrm{AB}$ report tersebut harus diadopsi oleh SEOM dan diterima tanpa syarat oleh pihak yang bersengketa kecuali SEOM memutuskan melalui konsensus untuk tidak mengadopsi $\mathrm{AB}$ report (negative consensus/reverse consensus) sebelum dalam kurun waktu 30 hari setelah diedarkan ke negara anggota lainnya.

Secara keseluruhan proses penyelesaian sengketa di bawah EDSM tidak boleh melebihi 445 hari, kecuali apabila terdapat keadaan yang terpaksa harus dilakukan lebih dari 445 hari sebagaimana diatur dalam Pasal 15. Hal ini menunjukan bahwa dalam proses pembentukan EDSM, negara-negara ASEAN menyadari perlu adanya batasan waktu dalam upaya penyelesaian sengketa agar tercipta kesepakatan yang efektif dan efisien.

Hal terakhir yang penting untuk diketahui adalah perkembangan penggunaan kerangka EDSM pada saat ini. Pada kenyataannya, hingga saat ini mekanisme penyelesaian sengketa pada kerangka EDSM melalui SEOM tidak pernah dipergunakan oleh anggota-anggota ASEAN sebagai forum penyelesaian sengketa perdagangan yang terjadi antar anggota. Perkembangannya hingga saat ini, dalam hal terjadinya sengketa perdagangan antar negara anggota ASEAN, negara-negara anggota ASEAN pada akhirnya cenderung memanfaatkan DSM WTO. Mengingat pentingnya pengaruh pengaturan baik di bidang ekonomi maupun sektor lainnya, maka tidak mengherankan jika anggota ASEAN tidak selalu setuju dengan tafsiran atau penerapan peraturan ini. Sengketa perdagangan biasa terjadi ketika suatu negara memutuskan untuk menerapkan kebijakan perdagangan tertentu yang bertentangan dengan komitmennya kepada WTO, atau ketika suatu negara membuat entry barrier kepada negara lain yang terkait dengan kebijakan yang dapat merugikan negara lain. Hal ini lah yang membuat negara-negara ASEAN lebih memilih DSM WTO daripada EDSM.

Hal tersebut dapat terlihat pada kasus antara Indonesia dengan Vietnam terkait tindak pengamanan pada produk besi atau baja pada tahun 2015 (DS496). Sengketa tersebut bahkan tidak dipertimbangkan untuk diselesaikan melalui mekanisme EDSM. Kedua belah pihak langsung mencari upaya penyelesaian melalui DSM WTO. Kecenderungan Indonesia dan Vietnam dalam memilih choice of forum disini disebebkan oleh keambiguan dalam Pasal 22 Piagam ASEAN yang menyebutkan 'resolve peacefully' dalam upaya menyelesaikan sengketa tanpa menyebutkan mengenai siapa pihak atau badan yang berwenang dalam menyelesaikan sengketa, apakah ASEAN, apakah WTO, atau bahkan apakah ICJ. Selain itu, Pasal 1 (3) EDSM juga memberikan keleluasaan kepada negara anggotanya untuk menentukan pilihan forum nya sendiri, dimana penggunaan EDSM secara tidak langsung bersifat tidak mutlak bagi negara anggota ASEAN.

ASEAN sebagai organisasi regional di kawasan Asia Tenggara tidak memiliki organ yang cukup kuat seperti halnya Uni Eropa yang dapat mengadopsi peraturan yang mengikat negara anggotanya secara hukum. Disisi lain, ASEAN begitu menekankan prinsip untuk menghargai kedaulatan dan independensi anggotanya. ASEAN juga tidak terlibat langsung dalam urusan domestik masing-masing anggotanya. ASEAN begitu menekankan prinsip good governance dan prinsip demokrasi sehingga membatasi Sekretaris Jenderal ASEAN dalam memberikan rekomendasi mengenai choice of forum di ASEAN. Piagam ASEAN juga tidak memberikan wewenang kepada Sekretaris Jenderal ASEAN untuk memaksa negara anggotanya untuk menyelesaikan sengketa melalui mekanisme ASEAN.

Hal ini memperlihatkan bahwa ASEAN sebenarnya tidak memiliki kekuatan yang cukup untuk membuat anggotanya menggunakan mekanisme penyelesaian sengketa ASEAN. 
Ditambah dengan kepentingan negara anggota ASEAN yang berbeda-beda, membuat ASEAN semakin sulit untuk menghendaki adanya penyelesaian sengketa perdagangan melalui mekanisme ASEAN. Seharusnya sengketa antara Indonesia dengan Vietnam diselesaikan melalui mekanisme penyelesaian sengketa yang diatur oleh ASEAN berdasarkan Regional Trade Agreement (RTA) mereka sendiri yang mengikat anggota ASEAN secara regional. Namun pada praktiknya, Piagam ASEAN tidak dapat memberikan kejelasan mengenai choice of forum kepada Indonesia dan Vietnam yang keduanya sama-sama merupakan anggota ASEAN dan WTO.

\subsection{Penyelesaian Sengketa Investasi Melalui ASEAN Comprehensive Investment Agreement}

Sebagai salah satu pilar ASEAN Community, AEC merupakan wujud dari keinginan negara anggota ASEAN untuk mempercepat transformasi kawasan Asia Tenggara menjadi kawasan yang lebih makmur, dan berdaya saing tinggi dengan langkah pemerataan pembangunan ekonomi, dan mengurangi dan bahkan menghilangkan kesenjangan ekonomi. Maksud dari eksistensi AEC adalah untuk menciptakan "single market and production base" yang didasarkan pada "free flow of goods, services, investments, capital, and skilled labour" yang tertuang dalam AEC Blueprint poin pertama. AEC diharapkan dapat menghilangkan sebagian besar hambatan perdagangan antar negara-negara anggota ASEAN, menciptakan fasilitasi perdagangan dan program harmonisasi kebijakan.

Dalam menunjang keinginan negara anggota ASEAN untuk mempercepat transformasi kawasan Asia Tenggara, salah satu langkah yang cukup solutif dalam upaya pembentukan AEC adalah dengan dipermudahnya arus investasi ke negara-negara yang berada di kawasan Asia Tenggara. Asia Tenggara menjadi destinasi investasi yang menjanjikan dengan melimpahnya sumber daya alam seperti minyak, gas, dan mineral. Dengan adanya AEC, iklim investasi di ASEAN, khususnya pada sektor pertambangan, meningkat secara drastis. Berdasarkan data World Bank, saat ini Foreign Direct Investment (selanjutnya disebut FDI) masih mendominasi dari total seluruh investasi asing di ASEAN.

Meningkatnya jumlah investasi dibidang pertambangan di ASEAN tentu memberikan dampak positif bagi negara anggota. Bagimana tidak, memanfaatkan sumber daya alam nya sebagai sumber pendapatan negara merupakan sebuah langkah cermat dalam menunjang pertumbuhan ekonomi di ASEAN. Namun meningkatnya investasi juga memiliki dampak negatif yang apabila tidak diperhatikan, menjadi kerugian bagi ASEAN itu sendiri. Industrialisasi sektor pertambangan seakan-akan memaksa negara untuk memperhatikan adanya potensi persoalan seperti perlindungan investasi, dan sengketa investasi antara investor dengan negara anggota ASEAN. Sebagai langkah preventif dari negara-negara ASEAN dalam menghadapi permasalahan-permasalahan yang timbul oleh adanya sengketa investasi, dibentuk ASEAN Comprehensive Investment Agreement (ACIA).

Sebenarnya ACIA bukanlah instrumen ASEAN pertama yang mengatur mengenai investasi asing, dan investasi intra-ASEAN. Sebelumnya ASEAN telah memiliki beberapa perjanjian terkait investasi, yakni:

a. Agreement among the Government of Brunei Darussalam, the Republic of Indonesia, Malaysia, the Republic of the Philippines, the Republic of Singapore, and the Kingdom of Thailand for the Promotion and Protection of Investments (1987)

b. Protocol to Amend the Agreement among the Governments of Brunei Darussalam, the Republic of Indonesia, Malaysia, the Republic of the Philippines, the Republic of Singapore, and the Kingdom of Thailand for the Promotion and Protection of Investments (1996)

c. Framework Agreement on the ASEAN Investment Area (1998)

d. Protocol to Amend the Framework Agreement on the ASEAN Investment Area (2001) 
Namun dengan dibentuknya ACIA sebagai perjanjian yang mengatur lebih rinci dan komprehensif terkait investasi, perjanjian-perjanjian tersebut dicabut dan dinyatakan tidak berlaku. Di Indonesia, pencabutan perjanjian-perjanjian tersebut tertuang dalam Pasal 3 Peraturan Pemerintah Nomor 49 Tahun 2011 tentang Pengesahan ASEAN Comprehensive Investment Agreement (Persetujuan Penanaman Modal Menyeluruh ASEAN).

ACIA yang ditandatangani oleh negara-negara anggota ASEAN pada 26 Februari 2009, dan berlaku efektif pada 29 Maret 2012, adalah perjanjian multilateral yang memberikan landasan hukum bagi liberalisasi investasi pada AEC. Tujuan dibentuknya ACIA adalah sebagai instrumen yang dapat meningkatkan ketertarikan investor asing untuk berinvestasi di ASEAN, agar terciptanya rezim investasi di ASEAN yang bebas, terbuka dan daerah investasi terpadu sebagaimana disebutkan dalam Pasal 1 ACIA.

Dengan meningkatnya iklim investasi di setiap negara anggota ASEAN, ASEAN membutuhkan suatu landasan hukum yang memberikannya perlindungan dan jaminan. Hal tersebut disadari oleh para negara anggota ASEAN bahwa dengan meningkatnya jumlah investasi, maka akan memperbesarkan kemungkinan dan resiko adanya sengketa yang dihadapi investor dan host state (negara anggota ASEAN). Berangkat dari alasan tersebut, negara-negara anggota ASEAN menyediakan empat pilar yang termuat dalam ACIA, yakni: liberalization, protection, facilitation, dan promotion. Berbicara mengenai perlindungan, ACIA menyediakan berbagai macam bentuk perlindungan bagi para investor yang hendak berinvestasi di ASEAN, yakni: Fair and equitable treatment (Pasal 11), Compensation in case of strife (Pasal 12), Freedom to transfer funds (Pasal 13), No unlawful expropriation (Pasal 14), dan Full protection and security (Pasal 17 dan 18).

Dalam menghadapi berbagai tantangan yang timbul dari meningkatnya iklim investasi di ASEAN, salah satu tantangan yang memerlukan perhatian khusus adalah dengan timbulnya sengketa antara investor asing dan host state. ACIA sebagai instrumen pengaturan investasi di ASEAN memiliki pengaturan yang mengatur mengenai mekanisme penyelesaian sengketa. Dalam Pasal 33 (1) ACIA disebutkan bahwa dalam rangka terjadinya sengketa antara negara anggota ASEAN dengan investor asing, investor asing diberikan hak untuk menyelesaikan sengketanya melalui beberapa pilihan mekanisme, yakni: melalui pengadilan negeri setiap negara (Pasal 33.1 (a)); melalui ICSID berdasarkan ICSID Convention, ICSID Rules of Procedure for Arbitration Proceedings, dan ICSID Additional Facility Rules (Pasal 33.1 (b),(c)); UNCITRAL Arbitration Rules (Pasal 33.1 (d)); Pusat Regional untuk Arbitrase di Kuala Lumpur (Pasal 33.1 (e)); dan Institusi arbitrase lainnya yang telah disepakati para pihak (Pasal 33.1 (f)).

Upaya penyelesaian sengketa melalui arbitrase dapat dilakukan apabila klaim atau gugatan dari investor merupakan sengketa dalam lingkup pelanggaran terhadap National Treatment (Pasal 5), Most-Favoured Nation Treatment (Pasal 6), Pengelola Senior dan Dewan Direksi (Pasal 8), Treatment of Investment (Pasal 11), Kompensasi dalam hal terjadinya kerusuhan (Pasal 12), Transfer (Pasal 13), Pengambilalihan dan kompensasi (Pasal 14), dan sengketasengketa terkait pengelolaan, pelaksanaan, pengoperasian, penjualan atau pelepasan lain terhadap suatu investasi yang dilindungi, sebagaimana dijelaskan pada Pasal 32 (a) ACIA.

Berdasarkan Pasal 31 (1) ACIA, dalam rangka terjadinya sengketa investasi antara investor dan host state, para pihak diwajibkan untuk mencari penyelesaian melalui mekanisme konsultasi dan negosiasi terlebih dahulu. Dalam melaksanakan konsultasi dan negosiasi, para pihak dapat menggunakan third party procedures yang sifatnya non-binding. Konsultasi tersebut dilakukan dengan cara pengajuan permohonan konsultasi dari investor asing yang bersengketa kepada host state yang merupakan negara anggota ASEAN. Pada Pasal 31 (2) ACIA, proses konsultasi antara pihak yang bersengketa harus dilaksanakan setidaknya dalam 
kurun waktu 30 hari, namun dapat disesuaikan (dilaksanakan lebih dari setelah 30 hari) apabila disetujui oleh para pihak.

Pengaturan pada Pasal 31 berimplikasi bahwa dalam hal terjadinya sengketa, investor asing tidak dapat langsung mengajukan klaim atau gugatan kepada host state sebelum melaksanakan upaya penyelesaian sengketa melalui konsultasi dan negosiasi. Namun apabila dalam kurun waktu 180 hari, para pihak bersengketa tidak menemukan solusi dan penyelesaian dari suatu sengketa, pihak investor asing dapat mengajukan klaim atau gugatan kepada lembaga atau institusi arbitrase yang telah disebutkan dalam Pasal 31 (1).

ACIA juga mengatur lebih lanjut mengenai prosedur pengajuan gugatan kepada arbitrase dalam hal terjadinya sengketa. Pada Pasal 33 (2) disebutkan bahwa pengajuan gugatan dapat dinyatakan diterima di lembaga arbitrase apabila notice of arbitration yang diajukan pihak investor telah memenuhi syarat sebagaimana diatur dalam peraturan arbitrase lembaga tersebut. Disini terlihat bahwa ACIA tidak berusaha membuat prosedur sendiri, melainkan bahwa pihak bersengketa harus menyelesaikan sengketanya berdasarkan peraturan lembaga arbitrase yang telah disepakati dalam ACIA.

Dalam hal pihak investor yang bersengketa handak mengajukan gugatannya ke lembaga arbitrase, pengajuan sengketa investasi ke arbitrase tersebut harus merupakan suatu kerugian atau dugaan pelanggaran yang telah berlangsung dalam kurun waktu 3 tahun dari waktu di mana investor yang bersengketa menyadari adanya pelanggaran kewajiban berdasarkan ACIA yang menyebabkan kerugian atau kerusakan pada investor yang bersengketa atau sengketa investasi yang telah disebutkan dalam Pasal 32 (a). Kemudian pihak investor yang bersengketa memberikan pemberitahuan tertulis, yang harus diserahkan setidaknya 90 hari sebelum gugatan diajukan, kepada negara anggota ASEAN yang bersengketa mengenai niatnya untuk mengajukan gugatan sengketa investasi ke arbitrase dan yang secara singkat merangkum dugaan pelanggaran negara anggota ASEAN yang bersengketa berdasarkan ACIA (termasuk ketentuan yang diduga telah dilanggar) dan kerugian atau kerusakan yang diduga disebabkan oleh investor yang bersengketa.

Kemudian sehubungan dengan pengaturan pada Pasal 34 (1) (c), pihak investor yang bersengketa tidak boleh dicegah untuk memulai atau melanjutkan niatannya untuk mengajukan gugatannya ke arbitrase untuk mengupayakan langkah-langkah perlindungan. Negara anggota ASEAN juga tidak diperbolehkan memberikan diplomatic protection sehubungan dengan sengketa yang telah disetujui oleh salah satu investornya dan negara anggota ASEAN lainnya untuk menyerahkan atau telah diserahkan ke arbitrase berdasarkan ACIA, kecuali negara anggota ASEAN lain tersebut gagal untuk melakukannya. Hal ini memberikan gambaran bahwa dalam hal terjadinya sengketa, negara anggota ASEAN lainnya (yang tidak bersengketa) tidak boleh melakukan intervensi yang dianggap tidak perlu.

Terlihat bahwa ACIA benar-benar berupaya memberikan perlindungan maksimal kepada investor asing untuk berinvestasi di ASEAN. Fasilitasi tersebut terlihat pada Pasal 34 (4) bahwa negara anggota ASEAN yang bersengketa tidak boleh melakukan pembelaan, tuntutan balasan, hak ganti rugi atau sebaliknya kepada pihak investor dalam rangka diajukan gugatan oleh pihak investor yang bersengketa.

Sebenarnya mengenai mekanisme penyelesaian sengketa di arbitrasenya merupakan aturan arbitrase pada umumnya, seperti halnya mengenai penunjukan satu arbiter dari masing-masing pihak bersengketa, dan arbiter ketiga yang akan ditentukan oleh arbiter-arbiter yang sudah ditentukan oleh para pihak dengan syarat bahwa arbiter ketiga tersebut bukanlah warga negara dari negara anggota ASEAN yang bersengketa, dan juga tidak berdomisili di di negara tersebut. Arbiter ketiga tersebut juga harus berasal dari negara yang memiliki hubungan diplomatik dengan negara yang bersengketa. Namun dalam hal ketika pengadilan arbitrasenya belum terbentuk selama 75 hari yang diakibatkan oleh tidak lengkapnya arbiter, maka pihak yang 
berwenang (dalam hal ini biasanya lembaga arbitrasenya) dapat diberikan kewenangan untuk menunjuk arbiter yang posisinya masih belum ada sesuai dengan persyaratan pada Pasal 35 (1), dan (2).

ACIA juga mengatur mengenai tata cara pelaksanaan arbitrase. Hal yang menarik untuk diperhatikan adalah mengenai hak dan kewajiban para pihak dalam pelaksanaan arbitrase. Setelah diajukannya gugatan kepada lembaga arbitrase oleh pihak investor yang bersengketa, negara anggota ASEAN yang bersengketa diberikan hak selambat-lambatnya 30 hari setelah pembentukan pengadilan (tribunal) untuk mengajukan keberatan mengenai gugatan yang diajukan oleh pihak investor yang bersengketa, seperti halnya keberatan mengenai yurisdiksi dan kompetensi pengadilan dalam melaksanakan arbitrase. Kemudian keberatan tersebut akan dibahas sebagai pertanyaan pendahuluan. Para pihak yang bersengketa harus diberi kesempatan yang wajar untuk menyampaikan pandangan dan pengamatan mereka ke pengadilan. Jika pengadilan memutuskan bahwa gugatan itu nyata tanpa alasan, atau sebaliknya tidak berada dalam yurisdiksi atau kompetensi pengadilan, maka pengadilan akan memberikan mengenai pandangan tersebut. Kemudian mengenai tempat pelaksanaan arbitrase, tempat pelaksanaannya dapat ditentukan berdasarkan peraturan lembaga arbitrase tersebut selagi berada di negara yang merupakan pihak pada New York Convention.

Hal yang cukup menarik adalah mengenai sengketa investasi yang berkaitan dengan masalah perpajakan. Dalam hal terjadinya sengketa akibat taxation measure, negara anggota ASEAN yang bersengketa dapat bersama negara anggota ASEAN yang tidak bersengketa dan lembaga berwenang yang menangani pajak pada negara anggota yang bersengketa, harus melaksanakan konsultasi terlebih dahulu untuk menentukan dan mencari tahu apakah gugatan yang diajukan benar-benar merupakan sengketa mengenai pajak. Hal tersebut juga demikian apabila sengketa pajak ini berkaitan dengan Expropriation and Compensation sebagaimana diatur dalam Pasal 14. Lalu apabila konsultasi tersebut tidak dilaksanakan oleh negara anggota yang bersengketa dalam kurun waktu 180 hari setelah diajukannya permohonan konsultasi oleh pihak investor yang bersengketa, maka pengajuan gugatan oleh pihak investor yang bersengketa tidak dapat dihalangi. Sebenarnya kewajiban para pihak untuk melaksanakan konsultasi terlebih dahulu berlaku dalam sengketa investasi jenis apapun yang termasuk dalam investasi yang dilindungi dalam ACIA, namun ACIA memberikan perhatian khusus kepada jenis sengketa terkait pajak, dimana hal tersebut secara spesifik disebutkan dalam Pasal 36 (6), (7), (8).

Berkaitan dengan hukum yang berlaku pada sengketa investasi yang diselesaikan melalui arbitrase, Pasal 40 (1) menjelaskan bahwa dalam upaya menyelesaikan sengketa melalui arbitrase, sumber hukum atau acuan pengadilan arbitrase dalam menyelesaikan sengketanya dapat berdasarkan ACIA, perjanjian yang berlaku antara negara anggota ASEAN yang bersengketa dengan negara dari pihak investor yang bersengketa seperti Bilateral Investment Treaty (selanjutnya disebut BIT), ketentuan hukum internasional yang berlaku seperti contohnya New York Convention, dan bahkan peraturan perundang-undangan negara anggota yang bersengketa apabila relevan terhadap sengketa tersebut.

Yang terakhir, berbicara mengenai hasil putusan akhir dari arbitrase, ACIA menyelaraskan ketentuannya berdasarkan peraturan lembaga arbitrase yang ditentukan para pihak bersengketa, khususnya pada ICSID dan UNCITRAL. Layaknya putusan arbitrase pada umumnya, putusan yang telah dikeluarkan oleh pengadilan arbitrase kepada para pihak yang bersengketa hanya berlaku bagi pihak-pihak yang bersengketa saja. Namun ketika pihak bersengketa ditengah proses pelaksanaan arbitrase merasa sudah menemukan sebuah solusi dari sengketa tersebut, dengan kesepatan kedua pihak sengketa tersebut dapat di berhentikan dan dinyatakan discontinued, bahkan juga demikian sebelum dikeluarkannya putusan pengadilan arbitrase.

ACIA telah memiliki beberapa Protokol perubahan yang pada umumnya mengatur ulang seperti mengenai reservasi, definisi natural person, dan berbagai perubahan teknis lainnya. 
Namun terkait penyelesaian sengketa, mekanisme yang diatur dalam ACIA tidak ada perubahan. Indonesia telah mengesahkan perubahan-perubahan tersebut melalui berbagai macam PP.

Pada dasarnya, ACIA mengatur hal-hal yang bersifat general atau umum, dimana ACIA diharapkan menjadi acuan negara-negara anggota ASEAN dalam menerapkan kebijakan investasi asingnya. Indonesia sendiri sebenarnya sudah memiliki undang-undang yang mengatur mengenai investasi, yakni: Undang-Undang Nomor 25 Tahun 2007 Tentang Penanaman Modal (UU PMA). Namun bicara mengenai penyelesaian sengketa, sebenarnya pengaturan di ACIA sedikit lebih rinci karena membahas mengenai prosedur dan menentukan "reasonable period of time" untuk mengajukan gugatan arbitrase. Pada Pasal 32 (1) UU PMA, disebutkan bahwa pihak bersengketa antara pemerintah Indonesia dengan investor (baik investor dalam negeri maupun asing) harus terlebih dahulu menyelesaikan sengketanya secara musyawarah mufakat. Hal tersebut selaras dengan Pasal 31 ACIA, namun dalam ACIA dijelaskan lebih rinci mengenai mekanisme konsultasinya. Pada Pasal 32 (4) UU PMA dijelaskan bahwa dalam hal terjadinya sengketa antara Indonesia dengan investor asing, sengketa tersebut harus diselesaikan melalui arbitrase Internasional.

Berdasarkan pengaturan pasal tersebut dapat ditafsirkan bahwa Indonesia tidak memberikan opsi untuk menyelesaikan sengketanya di pengadilan negeri sebagaimana diberikan pilihan oleh ACIA. Hal tersebut dibuktikan dengan beberapa sengketa investasi yang diselesaikan melalui berbagai lembaga arbitrase seperti ICSID, UNCITRAL, dan lain sebagainya. Kasus-kasus tersebut antara lain contohnya seperti sengketa antara pemerintah Indonesia dengan Kaltim Prima Coal (2007), Ravat Ali Rizvi (2011), Churchill Mining and Planet Mining Pty Ltd (2012 \& 2019), PT Newmont Nusa Tenggara (2009 \& 2014), Hesham Talaat M. Al Waraq (2014), Oleovest Pte Ltd (2016), dan lain sebagainya.

\section{KESIMPULAN}

Pada dasarnya ASEAN memiliki instrumen penyelesaian sengketa pada rezim perdagangan dan rezim investasi. Dalam EDSM, ruang lingkup sengketanya terbatas pada sengketa ekonomi saja. EDSM memiliki mekanisme penyelesaian sengketa yang serupa dengan mekanisme yang termuat dalam DSM WTO, yakni adanya panel dan Appelate Body sebagai badan banding. Namun hingga saat ini, mekanisme penyelesaian sengketa EDSM tidak pernah digunakan dalam sengketa perdagangan antar negara anggota ASEAN. Negara anggota ASEAN yang bersengketa cenderung lebih memanfaatkan DSM WTO. Hal tersebut dikarenakan pada ambiguitas Pasal 22 Piagam ASEAN yang menghendaki adanya penyelesaian sengketanya yang 'resolve peacefully' tanpa memberikan kejelasan mengenai siapa atau badan apa yang berwenang dalam menyelesaikan sengketa di ASEAN. Kemudian lemahnya ASEAN dalam menyikapi negara-negara anggotanya menjadi faktor penyebab pemilihan DSU WTO sebagai choice of forum dalam menyelesaikan sengketa perdagangan antar anggota ASEAN.

Kemudian ACIA sebagai intrumen investasi di ASEAN hadir sebagai upaya preventif negara anggota ASEAN dalam menghadapi arus investasi yang semakin tinggi. Untuk menyelesaikan sengketa investasi di ASEAN dapat diselesaikan melalui lembaga arbitrase antara lain: ICSID, UNCITRAL, Pusat Regional untuk Arbitrase di Kuala Lumpur, dan lembaga/institusi arbitrase lainnya yang disepakati para pihak bersengketa. Dengan diberlakukannya ACIA, negara-negara ASEAN harus mengharmonisasi kebijakan-kebijakan penanaman modal asingnya masing-masing dengan ACIA. Dalam hal yang berkaitan dengan penyelesaian sengketa, UU PMA yang dimiliki Indonesia memiliki pengaturan yang kurang lebih sama meskipun tidak rinci seperti pada ACIA. Namun dapat dipastikan bahwa pengaturan penyelesaian sengketa pada UU PMA dan ACIA tidaklah bertentangan. 


\section{DAFTAR PUSTAKA}

\section{Buku}

Adolf, Huala. Hukum Penyelesaian Sengketa Internasional. Cet. 2. Jakarta: Sinar Grafika, 2006.

Association of Southeast Asian Nations. ASEAN Economic Community Blueprint. Jakarta: ASEAN Secretariat, 2008.

Bossche, Peter Van den. The Law and Policy of the World Trade Organization. Ed.3. Cambridge: Cambridge University Press, 2005.

Direktorat Kerjasama ASEAN Kementerian Luar Negeri. ASEAN Selayang Pandang. Ed.19. Jakarta: Kementerian Luar Negeri, 2010.

\section{Jurnal}

A.A.A. Ngr. Sri Rahayu Gorda, Kadek Januarsa Adi Sudharma, dan Pipin Carolina BR Barus, "The Analysis of Tendency on Choice of Forum in the Settlement of Dispute of International Trade Among ASEAN Countries", Arena Hukum, Vol. 13, No. 1, 2020)

Koesrianti, “Analisa Kekuatan Mengikat Piagam ASEAN”, Yuridika, Vol. 26, No. 1, 2011.

Mangku, Dewa Gede Sudika. "Suatu Kajian Umum Tentang Penyelesaian Sengketa Internasional Termasuk Di Dalam Tubuh ASEAN", Jurnal Perspektif, Vol. 17, No. 3, 2012.

\section{Prosiding}

Fitriyanti, Fadia, dan Andika Putra. "Penyelesaian Sengketa Investasi Melalui Arbitrase Dalam Masyarakat Ekonomi ASEAN", Proceeding Paper Seminar Nasional, Universitas Muhammadiyah Yogyakarta, 2015.

Lestariningsih, Diah, dan Hening Kartika Nudya. "Risk Sensitive Investment in ASEAN: Problems and Solutions". Makalah pada International Conference on ASEAN Studies, 2014.

Sulistyawati, Dyah Ratih. "Gearing Up for ASEAN Economic Community: Small Medium Enterprises' Response and Preparedness to Regional Market Integration." Working Paper pada ASEAN Studies Centre, 2014.

\section{Internet}

Direktorat Kerjasama ASEAN Kementerian Luar Negeri. Kerjasama Ekonomi ASEAN. https://kemlu.go.id/.

ICSID Cases Database, https://icsid.worldbank.org/.

Tempo.co. Pemimpin ASEAN Tandatangani Bali Concord II. https://nasional.tempo. co/. (7 Oktober 2003).

UNCITRAL Clout Database, https://www.uncitral.org/.

World Trade Organization. DS496: Indonesia - Safeguard on Certain Iron of Steel Products, https://www.wto.org/. (1 Juni 2015).

Xinghua News Agency. Bali Concord II - Historic Step Toward Regional Integration, http://www.china .org.cn/. (8 Oktober 2003).

\section{Perjanjian Internasional}

Association of Southeast Asian Nations. ASEAN Protocol on Enhanced Dispute Settlement Mechanism. UNTS 177, 2004.

Association of Southeast Asian Nations. Charter of the Association of Southeast Asian Nations. UNTS 2624, 2007.

Association of Southeast Asian Nations. ASEAN Comprehensive Investment Agreement. 2009. 